\title{
Simultaneous Right-Sided Nephrectomy with Orthotopic Liver/Kidney Transplantation - An Alternative Method for Patients with Autosomal Dominant Polycystic Liver and Kidney Disease
}

Philipp Felgendreff ( $\nabla$ P.Felgendreff@gmail.com )

Universitatsklinikum Jena

Hans-Michael Tautenhahn

Universitatsklinikum Jena

Sascha Lux

Universitatsklinikum Jena

Felix Dondorf

Universitatsklinikum Jena

\section{Rene Aschenbach}

Universitatsklinikum Jena Institut fur Diagnostische und Interventionelle Radiologie

Falk Rauchfuß

Universitatsklinikum Jena

Utz Settmacher

Universitatsklinikum Jena

Research article

Keywords: kidney transplantation, liver transplantation, autosomal dominant polycystic liver and kidney disease

Posted Date: April 28th, 2020

DOI: https://doi.org/10.21203/rs.3.rs-21666/v1

License: () (i) This work is licensed under a Creative Commons Attribution 4.0 International License. Read Full License

Version of Record: A version of this preprint was published at Langenbeck's Archives of Surgery on May 26th, 2021. See the published version at https://doi.org/10.1007/s00423-021-02206-9. 


\section{Abstract}

Background: In patients suffering from autosomal dominant polycystic liver and kidney disease (ADPLKD), organ transplantation often poses a technical challenge due to the large volume of both organs. To simplify the transplantation procedure by improving the exposure of anatomical structures, we introduce a novel surgical technique.

Methods: Seven patients with ADPLKD were evaluated for simultaneous liver and kidney transplantation at the Jena University Hospital. The modified transplantation approach included hepatectomy and right-sided nephrectomy. After reperfusion of the liver graft, orthotopic kidney transplantation to the right-sided hemiabdomen was performed.

Results: Preoperatively, the median liver volume and right kidney volume were morphologically determined by CT to be $9343 \mathrm{ml}( \pm 3698.56)$ and $2770 \mathrm{ml}( \pm 1128.78)$. The mean operation time was 342.43 minutes ( \pm 68.77). Postoperatively, the patients were treated 6.28 days $( \pm 2.50)$ in the intensive care unit and were discharged from the surgical ward approximately 28 days $( \pm 5.66)$ after the operation with normal graft function.

Conclusion: The modified simultaneous liver and kidney transplantation technique is an effective alternative surgical transplantation method for patients with ADPLKD. The new transplantation technique simplifies the transplantation procedure by improving the exposure of anatomical structures.

\section{Background}

Since first reported by Margreiter et al. in 1984 (1), the simultaneous transplantation of the liver and kidney transplantation has been accepted as an effective surgical method in clinical practice, having a good patient outcome (2) and significantly improving the quality of life (3).

One indication for simultaneous organ transplantation is autosomal dominant polycystic liver and kidney disease (ADPLKD) (Potter III). In the presence of ADPLKD, kidney function can remain normal for a long time despite massive enlargement of the organ caused by the cysts (4). In $34 \%$ to $78 \%$ of patients with adult polycystic kidney disease, multiple liver cysts exist simultaneously (5) (6). The overall liver function in these patients is often maintained, but they may suffer from a number of nonspecific clinical symptoms, such as postprandial flank or abdominal pain, chronic nausea and vomiting, or shortness of breath. These symptoms often correlate with the size or position of the polycystic organs. Complications such as renal anemia, arterial/renal hypertension, cyst infection, significant weight loss, ureter or bile duct obstruction, nephrolithiasis, or hepatic venous-outflow obstruction can occur with disease progression.

The therapeutic procedure for ADPLKD is usually aligned to Gigot's classification (10). For type II and III ADPLKD patients, simultaneous liver and kidney transplantation provides the only curative treatment option (9) (11). In $42 \%$ of all patients with ADPLKD, simultaneous liver and kidney transplantation is necessary (12). In general, the simultaneous transplantation of these organs is a very rare procedure in the EUROTRANSPLANT region. Only forty-five combined transplantations were performed in 2017 (18), but only $15 \%$ of these were indicated for ADPLKD (19). 
Generally, the clinical standard transplantation procedure is based on two steps: 1.) the orthotopic liver transplantation, and 2.) the heterotopic kidney transplantation in the iliac fossa via a second surgical incision (two-step cLKTx). Currently, the surgical technique of simultaneous liver and kidney transplantation is subject to individual variability (13) and a center-specific approach (14) (15). The challenge in all existing surgical techniques is to reduce the clinical symptoms resulting from increased polycystic organ volume and to simplify the transplantation procedure by improving the representation, scope, and details of the anatomical structure.

In this article, we present the feasibility of a newly modified surgical technique for orthotopic simultaneous liver and kidney transplantation in patients with ADPLKD. Furthermore, we describe the three-month follow-up of patients with ADPLKD who have been transplanted with this modified technique as our standard since September 2016.

\section{Methods}

\section{Preoperative clinical parameters:}

The modified surgical technique of simultaneous liver and kidney transplantation has been used at the Transplantation Centre of the Jena University Hospital, Germany, since September 2016 as the standard operation technique for patients with ADPLKD. The respective patients underwent a comprehensive evaluation of possible contraindications. Furthermore, the internal interdisciplinary transplantation committee approved the indication for simultaneous organ transplantation prior to listing. The preoperative clinical parameters of the patients are derived from the internal hospital data reporting system as well as from the data transmitted to EUROTRANSPLANT. The characteristics of the donor and the recipient, along with the results of clinical routine examinations, were evaluated in the reported data analysis (ethical committee application number: 4428-05/15).

\section{Technique of the modified simultaneous liver and kidney transplantation:}

The abdominal cavity was opened up from the xiphoid down to the anterior superior iliac spine as a rightsided L-incision. The abdominal cavity was exposed by bilateral retraction of the ribcage to obtain access to the liver and the right kidney. Due to the increased volumes of the liver and the kidney, the preparation of the anatomical structures, especially the retrohepatic vena cava, can prove to be difficult. To simplify the procedure, individual cysts were opened during the preparation.

The right-sided nephrectomy of the polycystic altered organ was performed first to facilitate the hepatectomy, to simplify the transplantation procedure and to reduce the intra-abdominal volume. In preparation for this step, the right-sided colon and the duodenum were mobilized, and the renal vein and artery were identified and dissected. During nephrectomy, special attention must be paid to maintaining a long ureter with a surrounding mass of vessel-supplied tissue. 
Next, the liver was mobilized from the ligamentary structures and prepared for hepatectomy, including the retrohepatic vena cava. Before hepatectomy, the liver and kidney graft were prepared at the back table for the implantation.

Subsequently, the liver transplantation followed its usual course with the caval replacement technique and without the use of a temporary portocaval shunt or veno-venous bypass. Reperfusion was performed simultaneously, both portal and arterial. The bile duct was reconstructed as duct-to-duct modified end-end anastomoses.

After the completion of the liver transplantation, kidney transplantation in the orthotopic retroperitoneal position was performed via the pre-established right-sided L-incision. The venous anastomosis was made directly to the inferior $\mathrm{V}$. cava below the original stump of the right renal vein. Arterial reconstruction was established for the right common iliac artery of the recipient using an arterial interponate of the donor iliac artery, guided retroperitoneally for this means. After the reperfusion of the kidney graft and the preparation of the recipient ureter, an end-end uretero-ureterostomy was performed with a double- $J$ catheter splinting. The established L-incision was closed after inserting drainage tubes (two 20-gauge French tubes placed subhepatically and subphrenically).

\section{CT-scan and ultrasound imaging:}

As part of the routine evaluation procedure, a full-body computer tomography (CT-scan; CT Revolution 256 slice, GE Healthcare, USA) was performed for each potential recipient. The organ volume of the polycystic liver and kidney was calculated using Cerner SkyVue ${ }^{\circledR}$ Distribution (Version 2014.01.05, Cerner, USA) and the available CT-scan results. To visualize the transplanted organs and their vascular supply, clinically indicated postoperative CT-scans were reconstructed with MeVis ${ }^{(}$(Frauenhofer MeVis, Lübeck, Germany) (Fig. 1). To evaluate the postoperative course, the recipients underwent routine ultrasound examinations (Vivid S70, GE Healthcare, USA). During routine ultrasound exams, the perfusion of the transplanted organs was examined by determining the arterial and venous blood velocity and arterial vascular resistance.

\section{Results}

\section{Preoperative clinical parameters:}

Since 2016, the modified simultaneous liver and kidney transplantation technique has been the standard operation technique for patients suffering from ADPLKD at the Transplantation Centre of Jena University Hospital. Until October 2018, a total of seven patients were treated using this modified technique.

At the time of transplantation (Table 1), the patients were on average 54.14 years $( \pm 3.98$ ) old. Four of them were female. All patients had restricted liver function with a laboratory Model of End-Stage Liver Disease score (lab-MELD) of 18.57 points $( \pm 2.37$ ). All patients fulfilled the standard exceptional criteria for prioritization on the waiting list according to the EUROTRANSPLANT manual (standard exceptional Model of 
End-Stage Liver Disease (SE-MELD): 29.29 points $( \pm 2.06))(16)$. The average waiting time prior to the transplantation was 834.57 days $( \pm 832.23)$. The patients were categorized as ASA-score III with comorbidities such as normochromic normocytic anemia, renal hypertension, or type 2 diabetes. The mean body mass index (BMI) of the patients was $27.09 \mathrm{~kg} / \mathrm{m}^{2}( \pm 5.59)$. During the routine evaluation procedure, morphological analysis through a CT-scan revealed an average liver volume of $9343 \mathrm{ml}( \pm 3698.56)$ and an average right kidney volume of $2770 \mathrm{ml}( \pm 1128.78)$ (Table 2). All patients were categorized as type III according to Gigot's ADPLKD classification (Figs. 2 and 3). Donor-specific parameters are presented in Table 2.

Table 1

Preoperative clinical parameters of patients with ADPLKD evaluated for modified liver and kidney transplantation

\begin{tabular}{|c|c|c|c|c|c|c|c|c|}
\hline Patient-ID & $\begin{array}{l}\text { P- } \\
001\end{array}$ & P-002 & P-003 & $\begin{array}{l}\mathrm{P}- \\
004\end{array}$ & P-005 & P-006 & $\begin{array}{l}\text { P- } \\
007\end{array}$ & Average (SD) \\
\hline Age (y) & 52 & 50 & 57 & 54 & 61 & 55 & 50 & $\begin{array}{l}54.14( \pm \\
3.98)\end{array}$ \\
\hline Waiting time $(\mathrm{d})$ & 781 & 589 & 1032 & 2602 & 252 & 250 & 336 & $\begin{array}{l}834.57( \pm \\
832.23)\end{array}$ \\
\hline Gender & male & female & female & male & female & female & male & - \\
\hline $\begin{array}{l}\text { Preoperative } \\
\text { dialysis }\end{array}$ & no & no & yes & no & no & no & no & - \\
\hline Body weight $(\mathrm{kg})$ & 77 & 53 & 73 & 117 & 73 & 83 & 84 & $80( \pm 19.28)$ \\
\hline Body height (m) & 1.83 & 1.56 & 1.68 & 1.79 & 1.62 & 1.60 & 1.95 & $1.72( \pm 0.14)$ \\
\hline BMI $\left(\mathrm{kg} / \mathrm{m}^{2}\right)$ & 23.10 & 21.80 & 25.90 & 36.50 & 27.82 & 32.42 & 22.09 & $\begin{array}{l}27.09 \\
5.59)\end{array}( \pm$ \\
\hline Blood Typ (*) & $0(-)$ & $0(+)$ & $0(+)$ & $A(+)$ & $0(+)$ & $0(+)$ & $0(+)$ & - \\
\hline Lab-MELD & 17 & 15 & 20 & 19 & 20 & 17 & 22 & $\begin{array}{l}18.57( \pm \\
2.37)\end{array}$ \\
\hline SE-MELD & 29 & 33 & 29 & 29 & 26 & 29 & 30 & $\begin{array}{l}29.29 \\
2.06)\end{array}( \pm$ \\
\hline $\begin{array}{l}\text { Values are presen } \\
\text { Lab-MELD: labora } \\
\text { stage liver disease }\end{array}$ & $\begin{array}{l}\text { avera } \\
\text { nodel }\end{array}$ & $\begin{array}{l}\text { and sta } \\
\text { end stac }\end{array}$ & $\begin{array}{l}\text { lard dev } \\
\text { liver dis }\end{array}$ & $\begin{array}{l}\text { ion (S } \\
\text { se: } S E\end{array}$ & $\begin{array}{l}\text { * Rhesi } \\
\text { eld: star }\end{array}$ & $\begin{array}{l}\text { factor; B } \\
\text { ird exces }\end{array}$ & $\begin{array}{l}\text { Body } \\
\text { onal-m }\end{array}$ & $\begin{array}{l}\text { lass index; } \\
\text { lel of end }\end{array}$ \\
\hline
\end{tabular}


Table 2

Donor-, intraoperative- and organ-specific parameters in patients with modified liver and kidney transplantation

\begin{tabular}{|c|c|c|c|c|c|c|c|c|c|}
\hline & Patient-ID & P-001 & $\begin{array}{l}\mathrm{P}- \\
002\end{array}$ & $\begin{array}{l}\mathrm{P}- \\
003\end{array}$ & $\begin{array}{l}\text { P- } \\
004\end{array}$ & P-005 & $\begin{array}{l}\mathrm{P}- \\
006\end{array}$ & P-007 & $\begin{array}{l}\text { Average } \\
\text { (SD) }\end{array}$ \\
\hline \multirow{6}{*}{$\begin{array}{l}\text { Donor- } \\
\text { specific } \\
\text { parameter }\end{array}$} & Age & 55 & 79 & 61 & 72 & 63 & 61 & 51 & - \\
\hline & $\begin{array}{l}\text { Gender } \\
(\mathrm{M} / \mathrm{F})\end{array}$ & $M$ & $F$ & $F$ & $F$ & $\mathrm{~F}$ & $\mathrm{~F}$ & $\mathrm{~F}$ & - \\
\hline & $\begin{array}{l}\text { Body } \\
\text { weight } \\
\text { (kg) }\end{array}$ & 90 & 60 & 63 & 80 & 70 & 72 & 60 & - \\
\hline & $\begin{array}{l}\text { Body } \\
\text { height } \\
\text { (m) }\end{array}$ & 1.90 & 1.60 & 1.70 & 1.65 & 1.70 & 1.67 & 1.60 & - \\
\hline & $\begin{array}{l}\mathrm{BMI} \\
(\mathrm{kg} / \mathrm{m} 2)\end{array}$ & 24.90 & 23.40 & 21.80 & 29.40 & 24.20 & 25.80 & 23.40 & - \\
\hline & $\begin{array}{l}\text { Extended } \\
\text { donor }\end{array}$ & yes ${ }^{(1)}$ & $\begin{array}{l}\text { yes } \\
(2,3)\end{array}$ & $\begin{array}{l}\text { yes } \\
(1,3)\end{array}$ & $\begin{array}{l}\text { yes } \\
(1,2)\end{array}$ & $\begin{array}{l}\text { yes }(3, \\
4,5)\end{array}$ & $\begin{array}{l}\text { yes } \\
\text { (3) }\end{array}$ & yes ${ }^{(5)}$ & - \\
\hline \multirow[t]{5}{*}{$\begin{array}{l}\text { Intraoperative } \\
\text { parameter }\end{array}$} & $\begin{array}{l}\text { Operation } \\
\text { time } \\
\text { (min) }\end{array}$ & 326 & 236 & 288 & 413 & 322 & 419 & 393 & $\begin{array}{l}342.43 \\
( \pm 68.77)\end{array}$ \\
\hline & $\begin{array}{l}\text { CIT Liver } \\
\text { (min) }\end{array}$ & 420 & 516 & 535 & 497 & 395 & 621 & 208 & $\begin{array}{l}456( \pm \\
132.46)\end{array}$ \\
\hline & $\begin{array}{l}\text { WIT Liver } \\
(\mathrm{min})\end{array}$ & 25 & 31 & 32 & 29 & 32 & 56 & 46 & $\begin{array}{l}35.86( \pm \\
11.01)\end{array}$ \\
\hline & $\begin{array}{l}\text { CIT } \\
\text { Kidney } \\
\text { (min) }\end{array}$ & 559 & 563 & 648 & 457 & 488 & 741 & 550 & $\begin{array}{l}572.29 \\
( \pm 95.05)\end{array}$ \\
\hline & $\begin{array}{l}\text { WIT } \\
\text { Kidney } \\
\text { (min) }\end{array}$ & 12 & 10 & 21 & 10 & 20 & 21 & 34 & $\begin{array}{l}18.29( \pm \\
8.58)\end{array}$ \\
\hline \multirow{3}{*}{$\begin{array}{l}\text { Organ- } \\
\text { specific } \\
\text { parameter }\end{array}$} & $\begin{array}{l}\text { Liver vol. } \\
\text { (ml) }\end{array}$ & 11300 & 7394 & 6263 & 9867 & 10243 & 4576 & 15758 & $\begin{array}{l}9343( \pm \\
3698.56)\end{array}$ \\
\hline & $\begin{array}{l}\text { Kidney } \\
\text { vol. rig. } \\
\text { (ml) }\end{array}$ & 2931 & 1899 & 1408 & 4336 & 3881 & 1714 & 3221 & $\begin{array}{l}2770( \pm \\
1128.78)\end{array}$ \\
\hline & $\begin{array}{l}\text { Liver wt } \\
\text { (g) }\end{array}$ & 4500 & 3600 & 4220 & 4960 & 5585 & 1775 & 8210 & $\begin{array}{l}4692.86 \\
( \pm \\
1966.66)\end{array}$ \\
\hline \multicolumn{10}{|c|}{$\begin{array}{l}\text { Values are presented in average and standard deviation (SD); CT-volumetry using CT Revolution } 256 \\
\text { slice, GE Healthcare, USA; Cerner SkyVue® Distribution, version } 2014.01 .05 \text {, Cerner, USA; M: male, F: } \\
\text { female; BMI: Body mass index; wt: weight; vol: volume; Extended donor criteria reason: } 1 .: \text { non-traumatic } \\
\text { subarachnoid haemorrhage, }{ }^{2} .: \text { donor age, }{ }^{3} .: \text { ICU stay more than } 7 \text { days; }{ }^{4} .: \text { Cancer in medical history; }{ }^{5} .: \\
\text { Limited graft function }\end{array}$} \\
\hline
\end{tabular}




\begin{tabular}{|c|c|c|c|c|c|c|c|c|}
\hline Patient-ID & P-001 & $\begin{array}{l}\text { P- } \\
002\end{array}$ & $\begin{array}{l}\text { P- } \\
003\end{array}$ & $\begin{array}{l}\text { P- } \\
004\end{array}$ & P-005 & $\begin{array}{l}\text { P- } \\
006\end{array}$ & P-007 & $\begin{array}{l}\text { Average } \\
\text { (SD) }\end{array}$ \\
\hline $\begin{array}{l}\text { Kidney wt } \\
\text { (g) }\end{array}$ & 2000 & 1028 & 1900 & 3860 & 2908 & 984 & 1635 & $\begin{array}{l}2045( \pm \\
1032)\end{array}$ \\
\hline \multicolumn{9}{|c|}{$\begin{array}{l}\text { Values are presented in average and standard deviation (SD); CT-volumetry using CT Revolution } 256 \\
\text { slice, GE Healthcare, USA; Cerner SkyVue® Distribution, version } 2014.01 .05 \text {, Cerner, USA; M: male, F: } \\
\text { female; BMI: Body mass index; wt: weight; vol: volume; Extended donor criteria reason: } 1 .: \text { non-traumatic } \\
\text { subarachnoid haemorrhage, }{ }^{2} .: \text { donor age, }{ }^{3} .: \text { ICU stay more than } 7 \text { days; }{ }^{4} .: \text { Cancer in medical history; }{ }^{5} . . \\
\text { Limited graft function }\end{array}$} \\
\hline
\end{tabular}

\section{Intraoperative evaluation of simultaneous liver and kidney transplantation}

The mean operation time (Table 2) of the modified combined liver and kidney transplantation was 342.43 minutes $( \pm 68.77)$. The establishment of the vascular liver (WIT liver) and kidney (WIT kidney) anastomoses took 35.86 minutes $( \pm 11.01)$ and 18.29 minutes $( \pm 8.58)$, respectively.

On average, $785.71 \mathrm{ml}( \pm 393.40)$ of human albumin was infused to compensate for the intravascular volume deficiency. In only two patients was it necessary to compensate for the coagulopathy ROTEM driven by the transfusion of fresh frozen plasma (FFP).

\section{Postoperative evaluation of simultaneous liver and kidney transplantation:}

After leaving the operation theater, the patients were observed in the ICU for approximately 6.28 days ( \pm 2.50). Immediate extubation and hemodynamic stabilization were achieved in all patients.

In only one case did delayed kidney function occur. The initially impaired renal function in this patient (P002) resulted in hypervolemia with subsequent respiratory insufficiency. After reintubation and one-off hemodialysis (Table 3; Clavien-Dindo classification IVa), the kidney graft function stabilized promptly, and the patient could be transferred to the surgical ward on POD 11. During hospitalization, more than half of the patients had a minor complication, which was classified as type II according to the Clavien-Dindo classification. 
Table 3

Preoperative, postoperative and three-month follow-up parameters in patients with modified liver and kidney transplantation

\begin{tabular}{|c|c|c|c|c|c|c|c|c|}
\hline & Patient-ID & $\begin{array}{l}\text { P- } \\
001\end{array}$ & $\begin{array}{l}\mathrm{P}- \\
002\end{array}$ & $\begin{array}{l}\text { P- } \\
003\end{array}$ & $\begin{array}{l}\mathrm{P}- \\
004\end{array}$ & $\begin{array}{l}\text { P- } \\
005\end{array}$ & $\begin{array}{l}\text { P- } \\
006\end{array}$ & $\begin{array}{l}\text { P- } \\
007\end{array}$ \\
\hline \multirow[t]{3}{*}{ Preoperative } & CREA $(\mu \mathrm{mol} / \mathrm{l})$ & 277 & 257 & 531 & 356 & 334 & 360 & 542 \\
\hline & eGFR (ml/min) & 21.17 & 18.1 & 7.1 & 15.8 & 12.2 & 11.7 & 9.8 \\
\hline & UREA $(\mu \mathrm{mol} / \mathrm{l})$ & 17.1 & 15.9 & 14.7 & 4.7 & 20.6 & 18 & 21.8 \\
\hline \multirow[t]{10}{*}{$\begin{array}{l}\text { Postoperative } \\
\text { follow-up }\end{array}$} & $\begin{array}{l}\text { postoperative } \\
\text { Dialysis }(\mathrm{n})\end{array}$ & no & $\begin{array}{l}\text { yes } \\
\text { (1) }\end{array}$ & no & no & no & no & no \\
\hline & PRC (n) & 1 & 6 & 2 & 0 & 1 & 0 & 6 \\
\hline & $\operatorname{FFP}(n)$ & 0 & 0 & 0 & 0 & 0 & 0 & 0 \\
\hline & Albumin (ml) & 0 & 300 & 0 & 1000 & 500 & 0 & 650 \\
\hline & $\begin{array}{l}\text { Urine secretion POD } 1 \\
(\mathrm{ml})\end{array}$ & 7010 & 3140 & 5160 & 5600 & 780 & 2800 & 1500 \\
\hline & $\begin{array}{l}\text { Urine secretion POD } 2 \\
(\mathrm{ml})\end{array}$ & 3850 & 1800 & 2620 & 4100 & 6920 & 4200 & 3140 \\
\hline & $\begin{array}{l}\text { Urine secretion POD } 3 \\
(\mathrm{ml})\end{array}$ & 1430 & 990 & 2390 & 2900 & 1440 & 3850 & 2010 \\
\hline & ICU stay (d) & 4 & 11 & 8 & 4 & 5 & 6 & 6 \\
\hline & Hospitalisation (d) & 27 & 28 & 37 & 33 & 21 & 22 & 28 \\
\hline & Clavien-Dindo & II & IVa & Illa & II & II & Illa & II \\
\hline \multirow{9}{*}{$\begin{array}{l}\text { Three month } \\
\text { follow-up }\end{array}$} & AST $(\mu \mathrm{mol} / \mathrm{l})$ & 0.33 & 0.87 & 0.58 & 0.37 & 0.26 & 0.32 & 0.18 \\
\hline & $\operatorname{ALT}(\mu \mathrm{mol} / \mathrm{l})$ & 0.43 & 1.12 & 0.87 & 0.36 & 0.19 & 0.33 & 0.10 \\
\hline & $\operatorname{Ap}(\mu \mathrm{mol} / \mathrm{l})$ & 1.29 & 2.21 & 1.25 & 0.66 & 1.15 & 1.59 & 1.36 \\
\hline & $\mathrm{GGT}(\mu \mathrm{mol} / \mathrm{l})$ & 0.55 & 2.84 & 0.62 & 0.44 & 0.39 & 2.34 & 0.5 \\
\hline & $\operatorname{Lip}(\mu \mathrm{mol} / \mathrm{l})$ & 0.27 & 0.24 & 0.38 & 0.84 & 0.55 & 1.09 & 0.26 \\
\hline & CREA $(\mu \mathrm{mol} / \mathrm{l})$ & 112 & 134 & 73 & 148 & 83 & 141 & 164 \\
\hline & eGFR (ml/min) & 64.7 & 39.8 & 79.1 & 45.6 & 65.9 & 35.9 & 41.2 \\
\hline & UREA $(\mu \mathrm{mol} / \mathrm{l})$ & 9.2 & 5.1 & 3.5 & 10.7 & 6.3 & 8.3 & 8.9 \\
\hline & $\operatorname{ALB}(g / I)$ & 39 & 42 & 34 & 35 & 38 & 36 & 32 \\
\hline
\end{tabular}

AST: Aspartat-Aminotransferase, ALT: Alanin-Aminotransferase, AP: Alcaline phosphatase, GGT: - $^{-}$ Glutamyltransferase, Lip: Lipase, CREA: Creatinine, eGFR: estimated glomerular filtration rate, UREA: urea, ALB: Albumin, INR: international Normalized Ratio; BILI: bilirubin, ChE: Cholinesterase

PRC: packed red cells, FFP: fresh frozen plasma; POD: postoperative day 


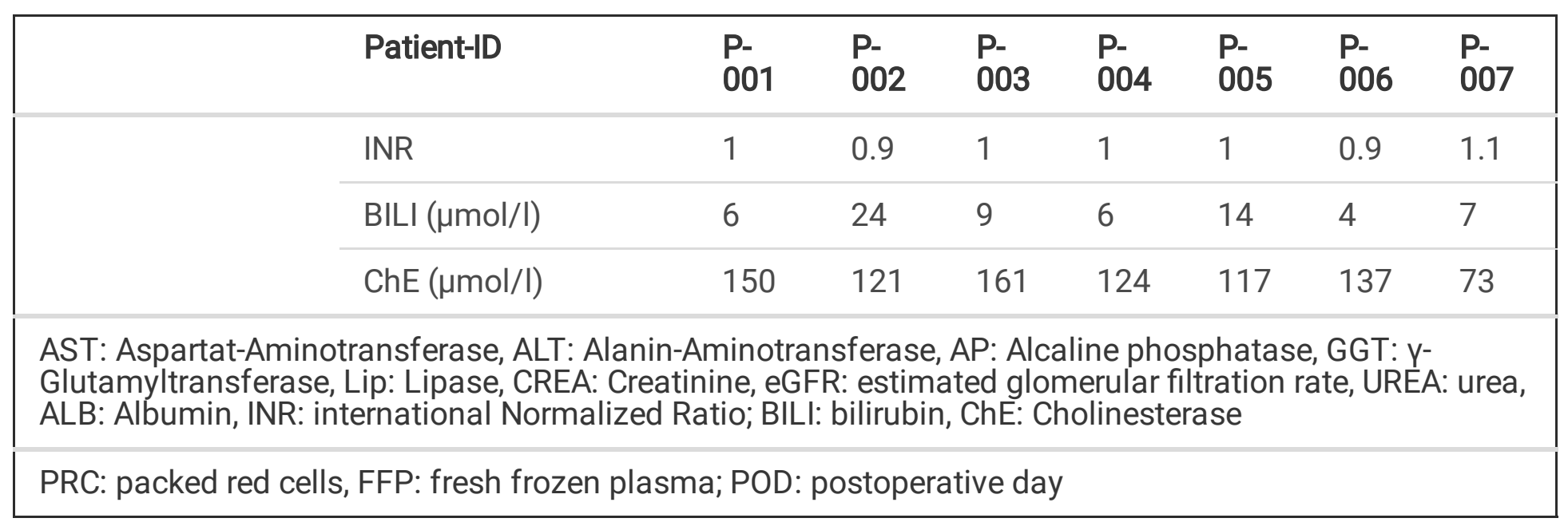

The graft function in the other six patients normalized promptly, and no irregularities occurred in the remaining clinical course of these patients. The routine ultrasound examination showed regular postoperative results with normal perfusion parameters and no signs of cholestasis or urinary retention (Table 4). There was no relevant postoperative bleeding. The immunosuppressive rules and standards based on tacrolimus (target level 8-12 $\mathrm{ng} / \mathrm{ml}$ within the first 3 months), mycophenolate, and steroids were gradually tapered, and were discontinued, depending on the patient, over a period of 6 months after transplantation. Basiliximab (20 mg at POD 0 and POD 4) was used for the immunosuppressive induction. Following the removal of the double-J catheter, patients were discharged after 28 days $( \pm 5.66)$ with normal liver and kidney function (data not shown). Furthermore, there was no manifestation of bile leakage, ureter stenosis, or incisional hernia during the postoperative observation period. 
Table 4

Sonographic findings using a Vivid S70 (GE Healthcare, USA) in the first three postoperative days in patients with modified liver and kidney transplantation

\begin{tabular}{|c|c|c|}
\hline & Parameters & Average (SD) \\
\hline \multirow[t]{6}{*}{ POD 1} & $\mathrm{PVF}(\mathrm{cm} / \mathrm{s})$ & $19.14( \pm 8.95)$ \\
\hline & $\mathrm{HAF}(\mathrm{cm} / \mathrm{s})$ & $59.67( \pm 39.02)$ \\
\hline & $\mathrm{RI}-\mathrm{HA}$ & $0.55( \pm 0.13)$ \\
\hline & $\operatorname{RVF}(\mathrm{cm} / \mathrm{s})$ & $25.55( \pm 28.35)$ \\
\hline & $\mathrm{RAF}(\mathrm{cm} / \mathrm{s})$ & $39.17( \pm 13.04)$ \\
\hline & RI-RA & $0.63( \pm 0.07)$ \\
\hline \multirow[t]{6}{*}{ POD 2} & $\mathrm{PVF}(\mathrm{cm} / \mathrm{s})$ & $28.33( \pm 10.56)$ \\
\hline & $\mathrm{HAF}(\mathrm{cm} / \mathrm{s})$ & $44.57( \pm 13.64)$ \\
\hline & RI-HA & $0.58( \pm 0.11)$ \\
\hline & $\operatorname{RVF}(\mathrm{cm} / \mathrm{s})$ & $12.5( \pm 0.71)$ \\
\hline & $\operatorname{RAF}(\mathrm{cm} / \mathrm{s})$ & $26.33( \pm 8.14)$ \\
\hline & RI-RA & $0.63( \pm 0.06)$ \\
\hline \multirow[t]{6}{*}{ POD 3} & $\mathrm{PVF}(\mathrm{cm} / \mathrm{s})$ & $29.52( \pm 16.81)$ \\
\hline & $\mathrm{HAF}(\mathrm{cm} / \mathrm{s})$ & $41( \pm 19.36)$ \\
\hline & RI-HA & $0.62( \pm 0.08)$ \\
\hline & $\mathrm{RVF}(\mathrm{cm} / \mathrm{s})$ & $14( \pm 4.24)$ \\
\hline & $\operatorname{RAF}(\mathrm{cm} / \mathrm{s})$ & $25.42( \pm 6.47)$ \\
\hline & RI-RA & $0.58( \pm 0.05)$ \\
\hline
\end{tabular}

The postoperative pathological examination (Table 2) confirmed the preoperative calculated liver and kidney dimensions (mean liver weight $4692.86 \mathrm{~g}$ ( \pm 1966.66); mean kidney weight $2045 \mathrm{~g}$ ( \pm 1032.78$)$ ). Opening single cysts during organ explantation is responsible for the difference between the pre- and postoperative examination.

The three-month follow-up confirmed excellent graft function (Table 3) with normal liver synthesis and normal kidney function (retention parameters) in all patients. The indication for additional left-sided nephrectomy was not given for any patient during the follow-up period. 


\section{Discussion}

The treatment of patients with ADPLKD is always individual. The respective strategies are oriented to the patients' individual symptoms as well as the patient- and organ-specific comorbidities. Controlling the symptoms associated with the cysts and preventing disease-specific complications are the primary aims of any therapy. In up to $90 \%$ (17) of all patients with ADPLKD, radiological or surgical interventions such as ethanol injection or cyst fenestration are the preferred therapy. By using these strategies, a transient reduction in symptoms can be achieved in approximately $92 \%$ of all patients (8) (9). Unfortunately, in $24 \%$ of these patients, the cysts reoccur. Depending on the therapy received, a morbidity rate of $23-50 \%$ and a mortality rate of $2-3 \%$ can be assumed (8) (9).

In patients with progressive symptoms and resulting comorbidities, transplantation remains the only curative treatment option. Transplantation can decrease the mortality and morbidity associated with the comorbidities and improve the quality of life (2) (3). Simultaneous liver and kidney transplantation, due to the massive cystic enlargement seen in ADPLKD, is technically challenging and varies depending on patients (13) and center-specific (14) (15) factors. This article demonstrates the secure feasibility of a new technique based on simultaneous orthotopic liver and kidney transplantation and right nephrectomy through a single incision in a sample of patients with ADPLKD.

Previously, Jochmans and colleagues (20) also described simultaneous organ transplantation through an individual median laparotomy. The kidney graft was placed in a retroperitoneal heterotopic position in the iliac fossa in a peritoneal pocket that was formed by peeling down the peritoneum from the midline (one-step cLKTx). Jochmans et al. documented a similar mortality and morbidity in the one-step cLKTx and the twostep cLKTx. Furthermore, the operation time (one-stage cLKTx $6.8 \mathrm{~h}(4.1 \mathrm{~h}-9.3 \mathrm{~h})$ vs. two-step cLKTx $9.0 \mathrm{~h}$ (8.7 h-10.1 h)), as well as the cold ischemic time (one-step cLKTx $8.1 \mathrm{~h}(6.4 \mathrm{~h}-9.3 \mathrm{~h}$ )), could be reduced using the modified technique (20).

The novelty of our modified technique is right-sided nephrectomy during combined transplantation. Compared to Jochmans et al., our modified liver and kidney transplantation procedure could reduce the operation time by more than one hour (one-stage cLKTx $6.8 \mathrm{~h}$ vs. orthotopic simultaneous liver and kidney transplantation $5.45 \mathrm{~h}$ ). This reduction is due to the right-sided nephrectomy. In addition, the right-sided nephrectomy facilitates the subsequent liver transplantation and the orthotopic transplantation of the kidney through the already prepared retroperitoneum. This surgical strategy results in a reduced intra-abdominal organ volume and improves the representation and detailed view of the anatomical structures during the preparation for hepatectomy and the implantation of the liver graft. Additionally, the vascular structures are openly accessible and can be prepared for subsequent kidney transplantation. Furthermore, the scar surface is reduced, since simultaneous transplantation can be carried out through a single incision.

Apart from the advantages of the modified transplantation technique, the morbidity and mortality rates are comparable with all established simultaneous transplantation techniques. Common perioperative complications after simultaneous transplantation are delayed graft function (18\%), infections $(24 \%)$ and cardiovascular complications (11\%) (23). The evaluation of the one-stage cLKTx of Jochmans et al. showed a complication rate of up to $25 \%$ according to the Clavien-Dindo classification $\geq$ III. This rate is similar to that 
of the classical transplantation method (20) as well as our modified simultaneous liver and kidney transplantation. Furthermore, surgical complications associated with our modification of the surgical technique were not observed. Except in one case, conservative therapeutic management successfully treated all complications. Additionally, frequent complications of heterotopic kidney transplantation, such as lymphocele, could be excluded by orthotropic transplantation of the kidney in the physiological position. Furthermore, the modified simultaneous organ transplantation reduced the ICU and in-hospital time of patients with ADPLKD. The patients spent, on average, 6.28 days $( \pm 2.50)$ in the ICU and 28 days $( \pm 5.66)$ in the hospital following the transplantation procedure. In contrast, patients who were transplanted using the standard transplantation technique spent an average of 9 days $( \pm 8.4)$ in the ICU and in total 33 days $( \pm 9.7)$ in the hospital (13).

The limitation for applying this modified transplantation technique is the obligatory nephrectomy. Each patient should be individually evaluated as to whether a simultaneous orthotopic liver and kidney transplantation with accompanying right-sided nephrectomy is the therapy of choice, which depends on the clinical symptoms of the patient and the intraoperative course. The median nephrectomy rate ranged from $33 \%$ (unilateral) to $67 \%$ (bilateral) (20) for all patients with ADPLKD, independent of the respective therapy strategy. Some transplant centers recommend a total nephrectomy before or during the transplantation in this patient group (21). However, simultaneous orthotopic transplantation with accompanying right-sided nephrectomy offers clear advantages over a two-sided procedure by sparing one operation, including narcosis, as well as improving the operative access during the transplantation procedure. In contrast to the indication for nephrectomy, there is less variability in the procedure of orthotopic liver transplantation. Usually, liver transplantation is performed either in vena cava interposition or using the "piggy-back" technique. Studies have consistently shown that there is no significant difference in graft or patient survival between the two techniques. Generally, the 1-year and 5-year survival rates after simultaneous liver and kidney transplantation are $88 \%$ and $80 \%$, respectively (22) (2) (3).

The interpretation of the results of the study is subject to further limitations. The small size of our study is one restriction and is due to the relatively rare procedure of simultaneous liver and kidney in the EUROTRANSPLANT region and the relatively rare prevalence of ADPLKD in the general population. Furthermore, simultaneous organ transplantation is considered in patients with type II and III ADPLKD (9) (11) according to Gigot's classification. Another restriction of the study is the currently missing long-term course of our patients treated with the modified orthotopic liver and kidney transplantation. However, these results are important to provide a comprehensive assessment of the modified technique.

In summary, the modified orthotopic liver and kidney transplantation technique is feasible and promising for patients suffering from polycystic liver and renal degeneration. The procedure yields a comparable mortality and morbidity rate to the classical transplantation method (13) (20). We were also able to demonstrate that our surgical technique reduced the relevant operation-specific parameters (operation time and warm ischemia time) compared to studies conducted using other techniques. Further experience and data are needed, especially in long-term outcomes, to clearly evaluate our promising results. Additionally, long-term surgical complications such as incisional hernia and vascular, bile duct or urinary complications are subjects for further research. Furthermore, the described modified surgical technique must be compared to the already 
established standard simultaneous orthotopic liver and heterotopic kidney transplantation. A prospective randomized clinical trial is planned to compare the modified orthotropic surgical technique with the clinical standard heterotopic operation procedure. These results will be used to consider broadening the application of the modified orthotropic surgical technique to other indications for combined transplantation in patients with end-stage liver and renal disease.

\section{Conclusion}

In conclusion, the modified orthotopic liver and kidney transplantation technique is an alternative technique for combined liver and kidney transplantation. The transplantation technique simplifies the transplantation procedure without negatively influencing the outcome of the patient.

\section{Abbreviations}

ADPLKD: Autosomal dominant polycystic liver and kidney disease

PDK-1: Pyruvate dehydrogenase kinase 1

PDK-2: Pyruvate dehydrogenase kinase 2

Two-step cLKTx: Standard simultaneous liver and kidney transplantation

Art: Arteria

V: Vena

Lig: Ligamentum

ICU: Intensive care unit

Lab-MELD: Laboratory Model of End-Stage Liver Disease

SE-MELD: Standard exceptional Model of End-Stage Liver Disease

BMI: Body mass index

CT-scan: Computed tomography

CRC: Concentrated red cells

FFP: Fresh frozen plasma

CIT: Cold ischemic time

WIT Warm ischemic time

PVF: Portal vein flow 
HAF: Hepatic artery flow

RI-HA: Resistance-Index hepatic artery

RVF: Renal vein flow

RAF: Renal artery flow

RI-RA: Resistance index-renal artery

POD: Postoperative day

AST: Aspartate aminotransferase

ALT: Alanine aminotransferase

AP: Alkaline phosphatase

GGT: y-Glutamyltransferase

Lip: Lipase

CREA: Creatinine

eGFR: Estimated glomerular filtration rate

UREA: Urea

ALB: Albumin

INR: International Normalized Ratio

BILI: Bilirubin

ChE: Cholinesterase

One-step cLKTx: Modified simultaneous liver and kidney transplantation according to Jochmans et al.

\section{Declarations}

\section{Ethics approval and consent to participate}

This retrospective database analysis study was approved by the institutional review board of University Hospital Jena Ethics Committee (ethical committee application number: 4428-05/15), and the requirement to obtain informed consent was waived.

\section{Consent for publication}

All authors consent to the publication. 
Availability of data and material

The datasets used and analyzed during the current study are available from the corresponding author on reasonable request.

\section{Competing interests}

The authors declare no competing interests.

\section{Funding}

This work was supported by funding of the Foundation "Else Kröner-Fresenius-Stiftung”.

\section{Authors' contributions}

All Authors read and approved the manuscript

PF designed the study, analyzed data and wrote the manuscript.

HMT analyzed data and wrote the manuscript

SL collected data and analyzed data.

FD collected data and analyzed data.

RA collected data and analyzed data.

FR collected data analyzed data and edited the manuscript

US designed the study, analyzed data and edited the manuscript.

\section{Acknowledgements}

Not applicable

\section{References}

1. Margreiter R, Kramar R, Huber C, Steiner E, Niederwieser D, Judmaier G, et al. Combined liver and kidney transplantation. Lancet (London, England) [Internet]. 1984 May 12;1(8385):1077-8.

2. Ueno T, Barri YM, Netto GJ, Martin A, Onaca N, Sanchez EQ, et al. Liver and kidney transplantation for polycystic liver and kidney-renal function and outcome. Transplantation. 2006;82(4):501-7.

3. Kirchner GI, Rifai K, Cantz T, Nashan B, Terkamp C, Becker T, et al. Outcome and quality of life in patients with polycystic liver disease after liver or combined liver-kidney transplantation. Liver Transpl [Internet]. 2006 Aug;12(8):1268-77.

4. Chapman AB, Bost JE, Torres VE, Guay-Woodford L, Bae KT, Landsittel D, et al. Kidney volume and functional outcomes in autosomal dominant polycystic kidney disease. Clin J Am Soc Nephrol [Internet]. 2012 Mar;7(3):479-86. 
5. Vauthey JN, Maddern GJ, Blumgart LH. Adult polycystic disease of the liver. Br J Surg [Internet]. 1991 May;78(5):524-7. Available from:.

6. Dumot JA, Fields MS, Meyer RA, Shay SS, Conwell DL, Brzezinski A. Alcohol sclerosis for polycystic liver disease and obstructive jaundice: use of a nasobiliary catheter. Am J Gastroenterol [Internet]. 1994 Sep;89(9):1555-7.

7. Kühn WE, Walz G. The Treatment of Autosomal Dominant Polycystic Kidney Disease. Dtsch Arztebl Int [Internet]. 2015 Dec 21;112(51-52):884-90.

8. Abu-Wasel B, Walsh C, Keough V, Molinari M. Pathophysiology, epidemiology, classification and treatment options for polycystic liver diseases. World J Gastroenterol [Internet]. 2013 Sep 21;19(35):5775-86.

9. Drenth JPH, Chrispijn M, Nagorney DM, Kamath PS, Torres VE. Medical and surgical treatment options for polycystic liver disease1. Hepatology. 2010;52(6):2223-30.

10. Gigot JF, Jadoul P, Que F, Van Beers BE, Etienne J, Horsmans Y, et al. Adult polycystic liver disease: is fenestration the most adequate operation for long-term management? Ann Surg [Internet]. 1997 Mar;225(3):286-94.

11. Bundesärztekammer. Richtlinie gemäß $\S 16$ Abs. 1 S. 1 Nrn. 2 u. 5 TPG für die Wartelistenführung und Organvermittlung zur Lebertransplantation. 2017;1-20.

12. Pirenne J, Aerts R, Yoong K, Gunson B, Koshiba T, Fourneau I, et al. Liver transplantation for polycystic liver disease. Liver Transpl [Internet]. 2001 Mar;7(3):238-45.

13. Moreno-Gonzalez E, Meneu-Diaz JC, Garcia I, Perez Cerdá F, Abradelo M, Jimenez C, et al. Simultaneous liver-kidney transplantation for adult recipients with irreversible end-stage renal disease. Arch Surg. 2004;139(11):1189-93.

14. Demirci G, Becker T, Nyibata M, Lueck R, Bektas H, Lehner F, et al. Results of combined and sequential liver-kidney transplantation. Liver Transpl [Internet]. 2003 Oct;9(10):1067-78.

15. Kornasiewicz O, Dudek K, Bugajski M, Najnigier B, Krawczyk M. Choice of transplantation techniques and indications for liver transplantation in polycystic liver disease in patients with no signs of end-stage liver disease. Transplant Proc [Internet]. 2008 Jun;40(5):1536-8.

16. Eurotransplant. Chapter 5 - ET Liver Allocation System (ELAS). Eurotransplant Man [Internet]. 2015.

17. Morino M, De Giuli M, Festa V, Garrone C. Laparoscopic management of symptomatic nonparasitic cysts of the liver. Indications and results. Ann Surg [Internet]. 1994 Feb;219(2):157-64.

18. Deutsche Stiftung Organtransplantation. Jahresbericht-organspende und transplantation in deutschland 2017 [Internet]. 2017 [cited 2019 Apr 9].

19. Mehrabi A, Fonouni H, Ayoub E, Rahbari NN, Müller SA, Morath C, et al. A single center experience of combined liver kidney transplantation. Clin Transplant [Internet]. 2009 Dec;23(Suppl 2):102-14.

20. Jochmans I, Monbaliu D, Ceulemans LJ, Pirenne J, Fronek J. Simultaneous liver kidney transplantation and (bilateral) nephrectomy through a midline is feasible and safe in polycystic disease. PLoS One [Internet]. 2017;12(3):1-10.

21. Martin AP, Bartels M, Kiehle A, Hauss J, Fangmann J. Polycystic liver and kidney disease: Post-transplant kidney function in patients receiving pre-emptive kidney transplantation. Transpl Int. 2008;21(3):263-7. 
22. Oppert M, Neumann U, Pascher A, Storm C, Lang T, Neuhaus R, et al. Langzeitüberleben nach kombinierter leber- und nierentransplantation. Transplantationsmedizin Organ der Dtsch Transplantationsgesellschaft. 2010;22(3):170-5.

23. Shekhtman G, Huang E, Danovitch GM, Martin P, Bunnapradist S. Combined Dual-Kidney Liver Transplantation in the United States: A Review of United Network for Organ Sharing/Organ Procurement and Transplantation Network Data Between 2002 and 2012. Liver Transpl [Internet]. 2018;24(11):15707.

\section{Figures}




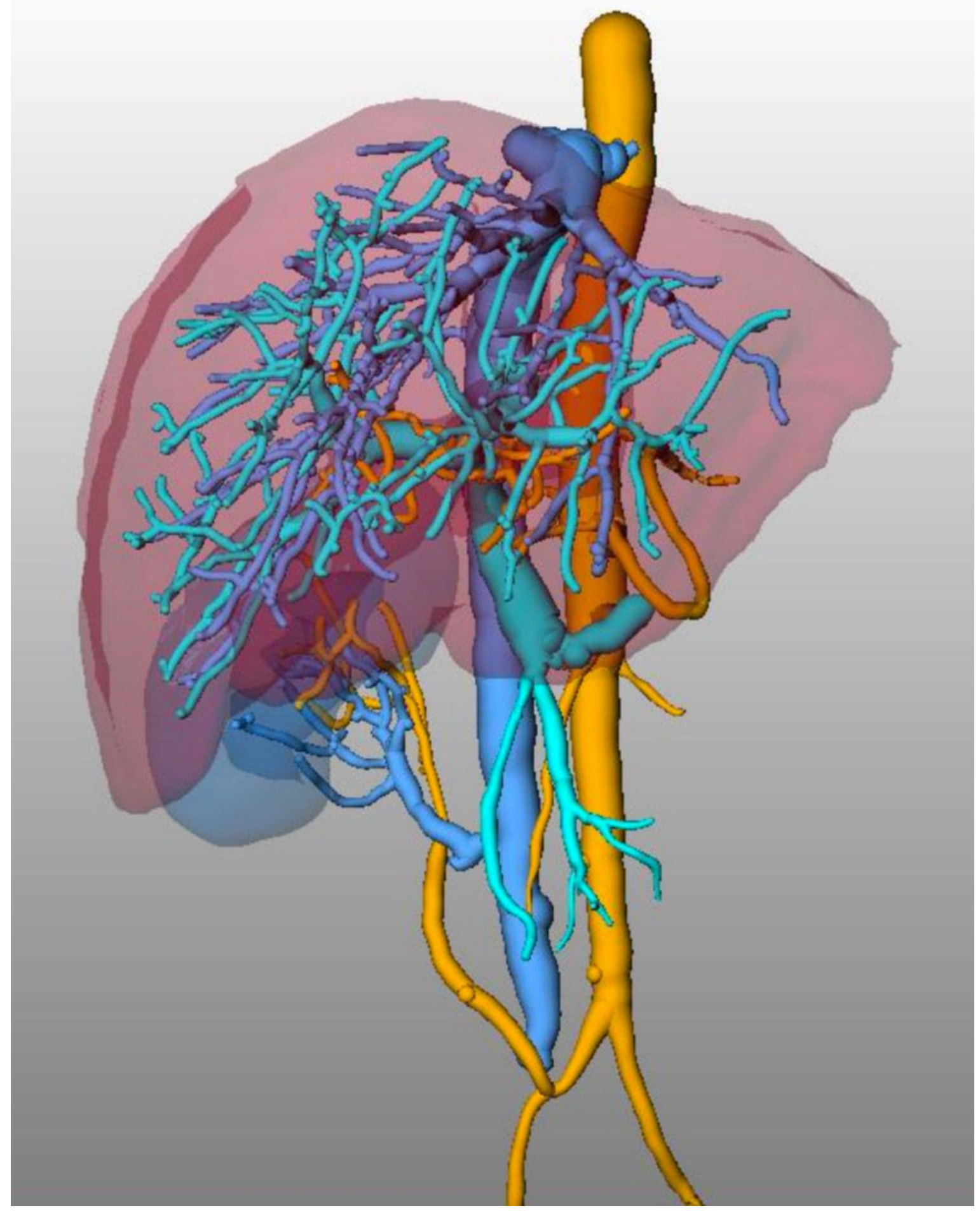

\section{Figure 1}

CT reconstruction (MeVis ${ }^{\circledR}$ (Frauenhofer MeVis, Lübeck, Germany)) after the transplantation of a patient with polycystic liver and kidney degeneration. Illustration of the transplant organs with arterial, portal, and venous vascular anatomy. 


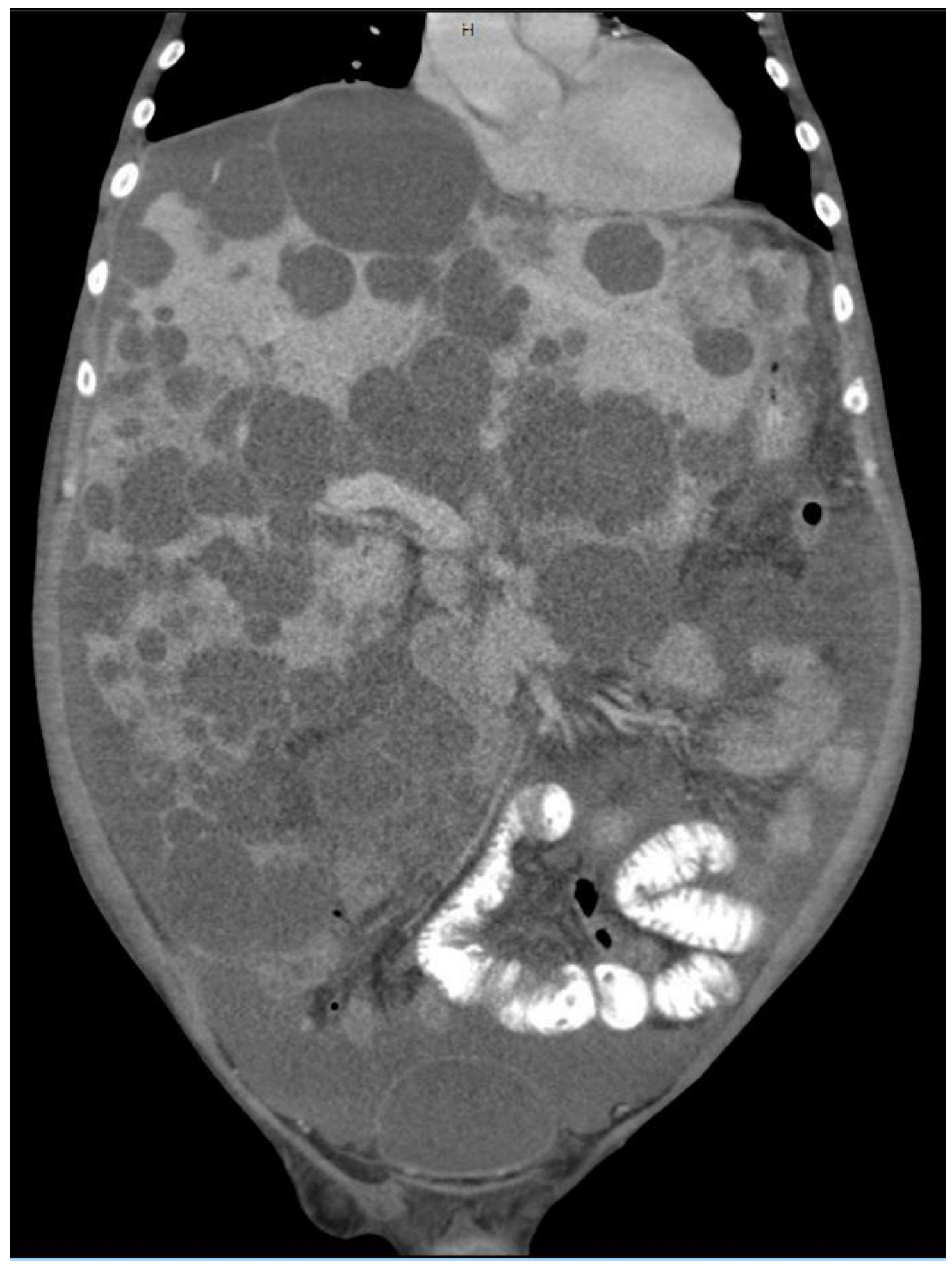

\section{Figure 2}

Coronal presentation of the portal vein in a polycystic liver. The kidneys are also polycystically degenerated as seen in the CT-scan (CT Revolution 256 slice, GE Healthcare, USA) before transplantation. 


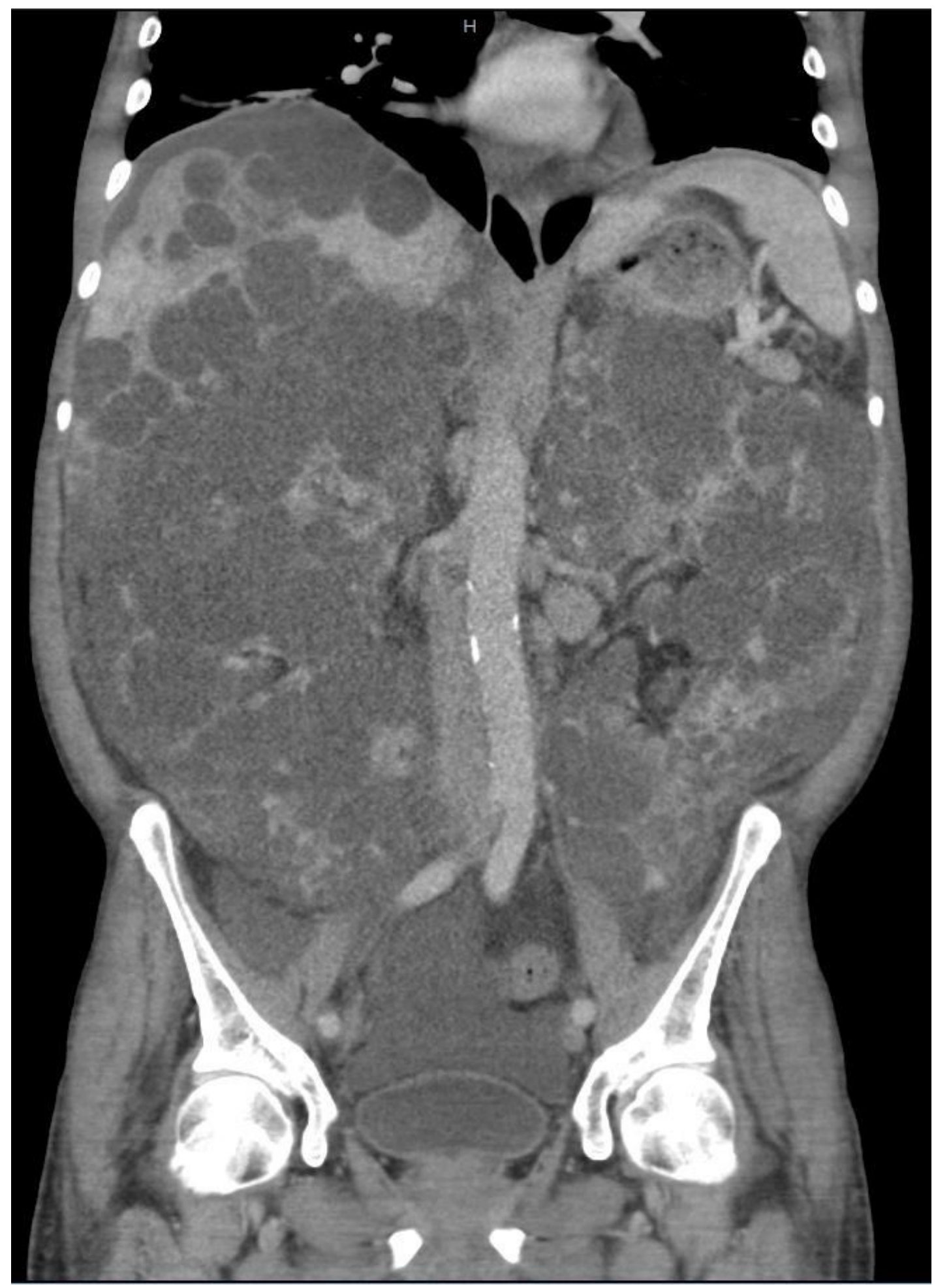

\section{Figure 3}

Coronal presentation of the portal vein in a polycystic liver. The kidneys are also polycystically degenerated as seen in the CT-scan (CT Revolution 256 slice, GE Healthcare, USA) before transplantation. 